\title{
Flypaper Effect Analysis on Local Government Budgets in Indonesia
}

\author{
Dina Syahrina and Ermawati
}

\begin{abstract}
This study aims to identify the effect of Local Own-Source Revenue, General Allocation Fund, Special Allocation Fund, Revenue Sharing Fund, Other Lawful Local Revenue, towards the Local Government Budget, as well as conduct the flypaper effect analysis. The object of this research is Districts/Cities in Indonesia. The samples used in this study consist of 472 Districts/Cities in Indonesia in the year 2018. The sampling technique used was the purposive sampling method with previously set criteria. The data used in this study is secondary data that originates from Local Government Financial Reports that are published by the Audit Board of the Republic of Indonesia. The hypothesis testing used in this study is the double linear regression analysis, using SPSS program version 20 with a significance rate of $5 \%$. The result of this study partially shows that Local Own-Source Revenue has a positive effect towards the Local Government Budget with a significance rate of 0,000 , General Allocation Fund has a positive effect towards the Local Government Budget with a significance rate of 0,000, Special Allocation Fund has a positive effect towards the Local Government Budget with a significance rate of 0,000 , Revenue Sharing Fund has a positive effect towards the Local Government Budget with a significance rate of 0,000 , and Other Lawful Local Revenue has a positive effect towards the Local Government Budget with a significance rate of 0,000 . The result of this study found the phenomenon of the flypaper effect towards Local Government Budget from the General Allocation Fund, while it was not found from the Special Allocation Fund and Revenue Sharing Fund.
\end{abstract}

Index Terms - Local own-source revenue, General allocation fund, Special allocation fund, Revenue sharing fund, Other lawful local revenue, Local government budget, Flypaper effect.

\section{INTRODUCTION}

Indonesia is one of the countries that implements a decentralization system for its governmental system. The use of the decentralization system allows the Central Government to give certain authorities to the Local Governments to govern and manage their own governmental affairs. The authority received by Local Governments from the Central Government is called State Autonomy. The implementation of state autonomy, which is a form of the implementation of the decentralization system, is in accordance with the Constitution of the Republic Indonesia Clause Number 32 Year 2004 on the Local Governments [30]. The Constitution of the Republic Indonesia Clause Number 33 Year 2004 on Financial Balance was ratifies in order to support funding on the diversion of authority to Local Governments as arranged in the Laws on Local Governments [31]. Financial balance

Published on July 28, 2020

Dina Syahrina, Universitas Pembangunan Nasional Veteran Jakarta, Indonesia.

(email: dina.syahrina@upnvj.ac.id). between the Central Government and the Local Governments comprises of the division of finance between the Central Government and the Local Governments proportionally, democratically, fairly, and transparently, while taking into account the potentials, conditions, and needs of the district The decentralization and state autonomy policy is essentially the improvement of past policies that were centralistic [22].

At present, several Local Governments still possess weaknesses with regards to allocation of revenue. Therefore, Local Governments are still not effective in executing their local budget. On average, almost $70 \%$ of the budget is still used for the operational needs of the Local Government, and therefore, the district's citizens have not yet optimally receive the benefits of the Revenue Budget and the Local Government Budget, receiving only approximately 30\% of the benefits, in which the portion of employee budget reaches $30 \%$. The use of the budget for goods and services expenditure, especially for business trips reaches approximately $13.4 \%$. Furthermore, expenditure for office services reaches approximately $17.5 \%$. Therefore, almost $70 \%$ of the Local Government Budget is used only for the people working in the Local Government itself. This is evidence that the Local Government does not allocate sufficient attention to capital expenditures, when capital expenditures potentially add to the value of fixed assets or other assets that provide long-term benefits for its respective district. Local Government Budgets that are predominantly used for employee expenditures can be deemed ineffective, and the people do not receive its benefits [21].

The summary of Local Government Budgets in the year 2018 regarding Local Expenditure Budget at the District/City level in Indonesia shows that the majority of expenditures are employee expenditures. In 2018, employee expenditures amounted to $35.6 \%$, goods and services expenditures amounted to $23.5 \%$, and other expenditures amounted to $21.6 \%$ [23]. Meanwhile, capital expenditures amounted to only $19.4 \%$. From that data, it is known that capital expenditure has the smallest percentage portion compared to other types of expenditures [20]. The summary shows that the Local Government Budget for local expenditure still prioritizes employee expenditures and other expenditures, when it should be used in balance and prioritizes capital expenditures, which has a longer benefit period, as well as has more productive value that could therefore improve the quality of public services.

At present, every district experiences the equal distribution of finances, in hopes of eliminating the fiscal gap between districts, since there is a fiscal balance transfer from 
the Central Government to the Local Governments. However, this causes the Local Governments to become highly dependent towards fund transfers from the Central Government, that comprises of the General Allocation Fund, Special Allocation Fund, and the Revenue Sharing Fund [9]. The allocation of the fiscal balance transfers is generally more focused towards expenditures, and focuses less on the capacity in improving Local Own-Source Revenue [28]. The effects of this phenomenon is that Local Governments, from year to year, always requests even larger transfers from the Central Government to fund Local Expenditures. Whereas, the Local Governments should focus more in exploring local tax bases more optimally in order to increase its Local OwnSource Revenue. If this condition persists, and the Local Governments relies its Local Expenditures more on transfers originating from the fiscal balance transfers instead of their Local Own-Source Revenue, it would cause the dissipation of the Local Expenditures. Therefore, this creates a phenomenon called the "Flypaper Effect".

This study aims to identify the effect of Local OwnSource Revenue, General Allocation Fund, Special Allocation Fund, Revenue Sharing Fund, Other Lawful Local Revenue, towards the Local Government Budget, as well as conduct the flypaper effect analysis.

\section{LITERATURE REVIEW}

\section{A. Agency Theory}

The agency theory is the relationship between two parties in a company, which are the principal, and the agent. The principal is the party that possess the contract, and the agent is the party that receives the [22]. In this theory, the principal will give a responsibility and authority to the agent, to execute tasks given by the principal on its own behalf. In reality, the principal and the agent will have different interests, in which the principal seeks more benefit since they are the party that gives the mandate and full authority on the company's operational activities.

The agency theory can be applied into the scope of the government, in which one party acts as the principal, that gives mandates, and another party acts as the agent that receives the mandate. In this context, the Local Government acts as both the principal and the agent. As an agent, the Local Government is given a mandate from the principal, which is the people, who are represented by the House of Representatives and the Central Government. This becomes one of the true forms that can become the subject of public attention, between the relationship of the agent and the principal [27].

\section{B. Local Expenditure}

In the Constitution of the Republic of Indonesia, Clause Number 32 Year 20005, local expenditure is all the district's responsibilities that are recognized as the subtractor of the net wealth in one budget year period. According to [19], local expenditure consists of all local cash expenditures in the relevant year that subtracts the wealth of the Local Government. Local expenditure according to [2] consists of all expenditures from the local general cash account that can subtract fund equity and the liability of the district within one budget year period in which no payback will be received by the district.

In the structure of the local budget with the performance approach, local expenditure can be detailed according to organization, function, category, and type of expenditure. The Local Government, in funding its local expenditures, uses funds from sources of local revenue retrieved either from its own local own-source revenue, and also from fiscal balance transfers from the Central Government [17].

\section{Hypothesis Development}

\section{Local Own-Source Revenue}

Local Own-Source Revenue is on of the fund sources to execute local expenditures. It is the revenue of a district that is gained from managing the potentials of the district, which generates revenue for itself. This is in accordance to the agency theory from the study conducted by [5], [27], in which the Local Government acts as the agent that receives authority from the Central Government, which acts as the principal to promote the people's welfare. In this context, the people also act as a principal, since they pay taxes and retribution to the Local Government, who acts as an agent. Therefore, as an agent, the Local Government must manage their revenues well. A study conducted by [27], [2], [26] found that Local Own-Source Revenue has an effect towards local expenditure. Therefore, based on the explanation above, the following hypothesis is formulated:

H1: Local own-source revenue has an effect towards local expenditure.

\section{General Allocation Fund}

The general allocation fund is one of the expenditure components found in the national budget, which becomes a revenue component in the local government budget. This is in accordance with the agency theory, in which the principal, the Central Government, gives fund aid in the form of the general allocation fund, so that the local government can execute its duty to improve the welfare of its people [4]. The Local Government as an agent must manage the received fund effectively and efficiently to determine which expenditure is of more importance and creates more benefit for the people. Therefore, the larger than General Allocation Fund received, the larger the budget for local expenditure [13], [32]. A study conducted by [14] states that the General Allocation Fund has an effect towards Local Expenditure. Therefore, based on the explanation above, the following hypothesis is formulated:

$\mathrm{H} 2$ : The general allocation fund has an effect towards local expenditure.

\section{Special Allocation Fund}

The Special Allocation Fund is one of the transfer funds given by the Central Government to the Local Governments to fund special activities that become the national priority, such as the building of infrastructure, and other public services. Therefore, the Special Allocation Fund received from the Central Government can aid Local Expenditure, which can be utilized to increase the quality of public service. In the agency theory, the Local Government as an agent must improve the quality of facilities and infrastructure for the interest of the principal, which in this case is the people. This is the mandate given from the Central Government, which also acts as a principal towards the Local Government. The 
Special Allocation Fund might affect Local Expenditure [13], [32]. A study conducted by [32], [18], and [1] states that the Special Allocation Fund affects Local Expenditure. Therefore, based on the explanation above, the following hypothesis is formulated:

H3: The special allocation fund has an effect towards local expenditure.

\section{Revenue Sharing Fund}

The Revenue Sharing Fund is a fund that originates from the revenue of from the National Budget that is allocated to districts based on a specific percentage, to fund the needs of the district in order to realize decentralization [26]. Based on the agency theory, the principal, which is the Central Government, will give funds to its agent, the Local Government, based on the profit-sharing percentage, in order to execute its duties in improving the welfare of the principal, which is the people. Therefore, the Revenue Sharing Fund will affect Local Expenditure in order to improve the welfare of the people. A study conducted by [32], [2], [27], [26] and [18] states that the Revenue Sharing Fund has an effect towards Local Expenditure. Therefore, based on the explanation above, the following hypothesis is formulated:

H4: The revenue sharing fund has an effect towards local expenditure.

\section{Other Lawful Local Revenue}

Other Lawful Local Revenue has an important role as a source for local funding. Based on the relationship between the components of local revenue, it can be stated that if other lawful local revenue experiences an increase, then the local expenditure will also increase, and vice versa. In the agency theory, the principal, which are the Central Government, the people, and corporations, provide additional funding to the Local Government as an agent, in order to increase regional development, which will be beneficial for the principal, the people, and other parties. A study conducted by [25], [29], and [3] states that other lawful local revenue has an effect towards local expenditure. Therefore, based on the explanation above, the following hypothesis is formulated:

H5: Other lawful local revenue has an effect towards local expenditure.

\section{Flypaper Effect}

Based on the Constitution of the Republic of Indonesia, Clause Number 33 Year 2004, the fiscal balance transfer is a fund transferred from the Central Government that aims to equally distribute the financial capacity of local governments in order to fund their local expenditure. However, this creates an issue in which the Local Governments have a tendency to utilize the fiscal balance transfer without optimizing the potentials of wealth in their district which in turn, creates the phenomenon of the flypaper effect. The flypaper effect is also supported by the agency theory, in which there is a principal, which is the Central Government, who monitors the activities of the Local Governments, who act as agents, to ensure that local finances are managed well, so that the Local Governments need not to depend on the Central Government's fund transfers. An agency problem exists, since the Local Government, as an agent, still depends on transfer funds instead of utilizing local own-source revenue. this is evidence that proves that the local governments are not yet optimal in managing its finances [11].
A study conducted by [6], [26] and [27] states that the flypaper effect phenomenon exists in the local expenditure. therefore, based on the explanation above, the following hypothesis is formulated:

H6: Fiscal balance transfer (general allocation fund, special allocation fund, and revenue sharing fund) has more effect towards the local expenditure, compared to the effect of local own-source revenue towards local expenditure.

\section{Research Methodology}

The population used in this study is all of the District/City governments in Indonesia in the year 2018, which amounts to 514, which consists of 416 Districts and 98 Cities. The sampling technique used in this study uses the purposive sampling method [8]. The total number of samples used in this study is 472, with a period of one year, which is 2018 . The hypothesis testing model used in this study is the double linear regression analysis, using SPSS version 20.

The dependent variable, which is Local Expenditure, is measured using calculations adopted from the study conducted by [12], [14], in which the local expenditure was totaled, and then transformed into natural logarithm. Local own-source revenue is measured using calculations adopted from the study conducted by [7], in which the local ownsource revenue is totaled, and then transformed into natural logarithm. The General Allocation Fund is measured using calculations adopted from the study conducted by [15], in which the general allocation fund is totaled, and then transformed into natural logarithm. The special allocation fund is measured using calculations adopted from the study conducted [14], in which the special allocation fund is totaled, and then transformed into natural logarithm. The revenue sharing fund is measured using calculations adopted from the study conducted by [14] in which the revenue sharing fund is totaled, and then transformed into natural logarithm. other lawful local revenue is measured using calculations adopted from the study conducted by [24], in which the other lawful local revenue is totaled, and then transformed into natural logarithm.

\section{RESUlts AND Discussion}

\section{A. Descriptive Statistics Analysis}

Local Expenditure shows that the lowest amount in the local government financial report in 2018 is found in the Konawe Islands District, with an Ln value of only 26.82, based on the nominal of Local Expenditure, which is Rp. $442,381,453,591.00$. Meanwhile, the highest amount is found in the Bandung District, with an Ln value of 29.15, based on the nominal of local expenditure of Rp.4,560,097,691,605.50. The average amount of Local Expenditure in Districts/Cities in the entirety of Indonesia amounts to an Ln value of 27.7576, which shows that the total amount of Local Expenditure amounts to approximately Rp. $1,128,973,189,958.37$.

Local Expenditure shows that the lowest amount in the local government financial report in 2018 is found in the Konawe Islands District, with an Ln value of only 26.82, 
based on the nominal of local expenditure, which is Rp. 442,381,453,591.00. Meanwhile, the highest amount is found in the Bandung District, with an Ln value of 29.15, based on the nominal of local expenditure of Rp. 4,560,097,691,605.50. The average amount of local expenditure in Districts/Cities in the entirety of Indonesia amounts to an ln value of 27.7576 , which shows that the total amount of local expenditure amounts to approximately Rp. $1,128,973,189,958.37$.

TABLE I: DESCRIPTIVE STATISTICS ANALYSIS

\begin{tabular}{llrrrr}
\hline & N & Minimum & Maximum & Mean & $\begin{array}{c}\text { Std. } \\
\text { Deviation }\end{array}$ \\
\hline LE & 443 & 26,82 & 29,15 & 27,7563 &, 44971 \\
LOR & 443 & 22,59 & 28,37 & 25,3963 & 1,04128 \\
GAF & 443 & 26,48 & 28,35 & 27,1897 &, 36508 \\
SAF & 443 & 24,01 & 27,33 & 25,9953 &, 49009 \\
RSF & 443 & 22,57 & 28,56 & 24,5751 & 1,08063 \\
OLLR & 443 & 17,12 & 27,61 & 24,5785 & 1,29048 \\
Valid N & 443 & & & & \\
\hline
\end{tabular}

Local own-source revenue shows the lowest amount in the local government financial report in 2018 is found in the Maybrat District, with an Ln value of only 22.59, based on the nominal of the Local Own-Source Revenue, which is Rp. $6,465,872,422.75$. Meanwhile, the highest amount of the Local own-source revenue is found in the Bekasi District, with an $\mathrm{Ln}$ value of 28.37 , based on the nominal of the Local Own-Source Revenue, which is Rp. 2,094,369,342,687.00. The average amount of local own-source revenue expenditure in Districts/Cities in the entirety of Indonesia amounts to an Ln value of 25.3960, which shows that the total amount of Local Own-Source Revenue amounts to approximately Rp. $106,289,385,325.54$.

General allocation fund shows the lowest amount in the local government financial report in 2018 is found in the Konawe Islands District, with an Ln value of only 26.48, based on the nominal of the general allocation fund, which is Rp. 315,499,213,000.00. Meanwhile, the highest amount of the general allocation fund is found in the Bandung District, with an Ln value of 28.35, based on the nominal of the General Allocation Fund, which is Rp. 2,060,202,697,000.00. The average amount of the general allocation fund in Districts/Cities in the entirety of Indonesia amounts to an Ln value of 27,1889 , which shows that the total amount of the general allocation fund amounts to approximately Rp. $637,391,140,000,00$.

Special allocation fund shows the lowest amount in the local government financial report in 2018 is found in Serang City, with an Ln value of only 24.01, based on the nominal of the Special Allocation Fund, which is Rp. 26,626,702,999.00. Meanwhile, the highest amount of the Special Allocation Fund is found in the Bandung District, with an Ln value of 27.33, based on the nominal of the special allocation fund, which is Rp. 737,019,669,306.00. The average amount of the special allocation fund in Districts/Cities in the entirety of Indonesia amounts to an $\mathrm{Ln}$ value of 25,9951, which shows that the total amount of the special allocation fund amounts to approximately Rp. 192,980,604,384.00.

The revenue sharing fund shows the lowest amount in the local government financial report in 2018 is found in the Sabu Raijua District, with an Ln value of only 22.57 , based on the nominal of the Revenue Sharing Fund, which is Rp.
$6,356,039,810.00$. Meanwhile, the highest amount of the revenue sharing fund is found in the Bojonegoro District, with an Ln value of 28.56 , based on the nominal of the Revenue Sharing Fund, which is Rp. 2,532,807,898,432.00. The average amount of the revenue sharing fund in Districts/Cities in the entirety of Indonesia amounts to an $\mathrm{Ln}$ value of 24.5839, which shows that the total amount of the Revenue Sharing Fund amounts to approximately Rp. 46,829,082,756.

Other lawful local revenue shows the lowest amount in the local government financial report in 2018 is found in the Banyuasin District, with an Ln value of only 17.12 based on the nominal of other lawful local revenue, which is $\mathrm{Rp}$. 27,215,581.00. Meanwhile, the highest amount of the Revenue Sharing Fund is found in the Cianjur District, with an Ln value of 27.61, based on the nominal of other lawful local revenue, which is Rp. 981,962,952,896,00. The average amount of other lawful local revenue in Districts/Cities in the entirety of Indonesia amounts to an Ln value of 24.5785 , which shows that the total amount of other lawful local revenue amounts to approximately $\mathrm{Rp.}$ 46,900,158,894,00.

\section{B. Results}

The results of the hypothesis testing of this study can be seen in Table II. The first hypothesis is that local own-source revenue affects Local Expenditure. The analysis conducted using the partial test (T-test) shows that local own-source revenue has a calculated $\mathrm{T}$-value of 21.314 and a table $\mathrm{T}$ value of 1.965407 with a significance rate of 0.000 . Therefore, it can be concluded that the calculated T-value > table T-value $(21.314>1.965407)$ and a significance rate of $1<0.05(0.000<0.005)$. The coefficient value of the local own-source revenue has a positive value, which means that the higher the local own-source revenue, the higher the Local Expenditure is. Therefore, it can be concluded that $\mathrm{H}_{\mathrm{a} 1}$ is accepted, which means that local own-source revenue has a positive effect towards local expenditure. This means that the local own-source revenue possessed by a local government increases along with the local expenditure that is funded by local own-source revenue.

\begin{tabular}{|c|c|c|c|c|c|}
\hline \multirow[t]{2}{*}{ Model } & & \multicolumn{2}{|c|}{$\begin{array}{l}\text { Unstandardized } \\
\text { Coefficients }\end{array}$} & \multirow[t]{2}{*}{$\mathrm{t}$} & \multirow[t]{2}{*}{ Sig. } \\
\hline & & B & Std. Error & & \\
\hline & (Constant) & 1,707 & ,422 & 4,043 & ,000 \\
\hline & LOR & , 139 & ,007 & 21,314 & ,000 \\
\hline & GAF & 633 & ,026 & 23,958 &, 000 \\
\hline & SAF & ,101 & ,017 & 5,877 & ,000 \\
\hline & RSF & 089 & ,005 & 17,821 &, 000 \\
\hline & OLLR & ,020 & ,004 & 4,374 & ,000 \\
\hline
\end{tabular}

\section{The Effect of Local Own-Source Revenue towards} Local Expenditure

This result is in line with the study conducted by [14], which used samples of District/City Governments in the years 2015-2016. This study states that Local Own-Source Revenue has an effect towards Local Expenditure. [27] conducted a similar study which used samples from District/City Governments in the West Java Province in the years 2009-2013. This study also states that states that Local Own-Source Revenue has an effect towards Local 
Expenditure. Another study by [22] used samples from District/City Governments in the East Kalimantan Province in the years 2011-2016. This study also states that states that local own-source revenue has an effect towards local expenditure. This researcher also states that states that local own-source revenue has an effect towards local expenditure. Similarly, [26] conducted the same study using samples from District/City Governments in the Bali Province in the years 2005-2012. This study also states that states that Local OwnSource Revenue has an effect towards Local Expenditure.

2. The Effect of the General Allocation Fund towards Local Expenditure

The second hypothesis is that the General Allocation Fund affects Local Expenditure. The analysis conducted using the partial test (T-test) shows that the General Allocation Fund has a calculated T-value of 23.958 and a table T-value of 1.965407 , with a significance rate of 0.000 . Therefore, it can be concluded that the calculated $\mathrm{T}$-value $>$ table $\mathrm{T}$-value $(23.958>1.965407)$ and a significance rate of $<0.05(0.000$ $<0.005)$. The coefficient value of the general allocation fund has a positive value, which means that the higher the general allocation fund, the higher the local expenditure. Therefore, it can be concluded that $\mathrm{H}_{\mathrm{a} 2}$ is accepted, which means that the General Allocation Fund has a positive effect towards Local Expenditure. This means that the general allocation fund possessed by a local government increases along with the local expenditure that is funded by the general allocation fund.

This result is in line with the study conducted by [14], which used samples of District/City Governments in the East Java Province in the years 2015-2016. This study states that the general allocation fund has an effect towards local expenditure. [32] conducted a similar study which used samples from District/City Governments in the South Sumatra Province in the years 2013-2015. Similarly, researchers [22] conducted the same study using samples from District/City Governments in the South Sumatra Province but for the earlier years 2008-2011. This study also states that the general allocation fund has an effect towards local expenditure. Another study by [27] used samples from District/City Governments in the West Java Province in the years 2009-2013. This study also states that states that the general allocation fund has an effect towards Local Expenditure. [27] also used samples from District/City Governments in the Jambi Province in the years of 20102014. This researcher also states that states that the general allocation fund has an effect towards local expenditure.

3. The Effect of the Special Allocation Fund towards Local Expenditure

The third hypothesis is that the special allocation fund affects local expenditure. The analysis conducted using the partial test (T-test) shows that the special allocation fund has a calculated T-value of 5.877 and a table T-value of 1.965407 , with a significance rate of 0.000 . Therefore, it can be concluded that the calculated $\mathrm{T}$-value $>$ table $\mathrm{T}$-value $(5.877$ $>1.965407)$ and a significance rate of $<0.05(0.000<0.005)$. The coefficient value of the special allocation fund has a positive value, which means that the higher the special allocation fund, the higher the local expenditure. Therefore, it can be concluded that $\mathrm{H}_{\mathrm{a}}$ is accepted, which means that the special allocation fund has a positive effect towards local expenditure. This means that the special allocation fund possessed by a local government increases along with the local expenditure that is funded by the special allocation fund.

This result is in line with the study conducted by [15], which used samples of District/City Governments in the East Java Province in the years 2015-2016. This study states that the General Allocation Fund has an effect towards Local Expenditure. [32] conducted a similar study which used samples from District/City Governments in the South Sumatra Province in the years 2013-2015. Similarly, researchers [22] conducted the same study using samples from District/City Governments in the South Sumatra Province but for the earlier years 2008-2011. This study also states that states that the general allocation fund has an effect towards local expenditure. This study also states that states that the General Allocation Fund has an effect towards Local Expenditure. Another study by [27] used samples from District/City Governments in the West Java Province in the years 2009-2013. This study also states that states that the general allocation fund has an effect towards local expenditure. [27] also used samples from District/City Governments in the Jambi Province in the years of 20102014. This researcher also states that states that the general allocation fund has an effect towards local expenditure.

This result is in line with the study conducted by [32], which used samples of District/City Governments in the South Sumatra Province in the years 2013-2015. This study states that the Special Allocation Fund has an effect towards Local Expenditure. [18] conducted a similar study which used samples from all District/City Governments in Indonesia in the years 2014-2016. This study states that the Special Allocation Fund has an effect towards Local Expenditure. Similarly, researchers [1] conducted the same study using samples from District/City Governments in the East Java Province in the years 2005-2012. This study also states that states that the Special Allocation Fund has an effect towards Local Expenditure.

4. The Effect of the Revenue Sharing Fund towards Local Expenditure

The fourth hypothesis is that the revenue sharing fund affects local expenditure. The analysis conducted using the partial test (T-test) shows that the revenue sharing fund has a calculated T-value of 17.821 and a table T-value of 1.965407 with a significance rate of 0.000 . Therefore, it can be concluded that the calculated T-value $>$ table T-value $(17.821$ $>1.965407)$ and a significance rate of $<0.05(0.000<0.005)$. The coefficient value of the revenue sharing fund has a positive value, which means that the higher the revenue sharing fund, the higher the local expenditure. Therefore, it can be concluded that $\mathrm{H}_{\mathrm{a} 4}$ is accepted, which means that the revenue sharing fund has a positive effect towards local expenditure. This means that the revenue sharing fund possessed by a local government increases along with the local expenditure that is funded by the revenue sharing fund.

This result is in line with the study conducted by [32], which used samples of District/City Governments in the South Sumatra Province in the years 2013-2015. This study states that the revenue sharing fund has an effect towards local expenditure. Another study by [27] used samples from District/City Governments in the West Java Province in the years 2009-2013. This study also states that states that the 
revenue sharing fund has an effect towards local expenditure. This study also states that states that the revenue sharing fund has an effect towards local expenditure. [18] conducted a similar study which used samples from all District/City Governments in Indonesia in the years 2014-2016. This study states that the revenue sharing fund has an effect towards local expenditure. Similarly, researchers [26] conducted the same study using samples from District/City Governments in the Bali Province in the years 2005-2012. This study also states that the revenue sharing fund has an effect towards local expenditure.

5. The Effect of Other Lawful Local Revenue towards Local Expenditure

The fifth hypothesis is that other lawful local revenue affects local expenditure. The analysis conducted using the partial test (T-test) shows that the other lawful local revenue has a calculated T-value of 4.374 and a table T-value of 1.965407 with a significance rate of 0.000 . Therefore, it can be concluded that the calculated $\mathrm{T}$-value $>$ table $\mathrm{T}$-value $(4.374>1.965407)$ and a significance rate of $<0.05(0.000<$ $0.005)$. The coefficient value of other lawful local revenue has a positive value, which means that the higher the other lawful local revenue, the higher the local expenditure. Therefore, it can be concluded that $\mathrm{H}_{a 5}$ is accepted, which means that other lawful local revenue has a positive effect towards local expenditure. This means that other lawful local revenue possessed by a local government increases along with the local expenditure that is funded by other lawful local revenue.

This result is in line with the study conducted by [29], which conducted research using samples from Districts in the Minahasa Province in the years 2002-2016. The study stated that other lawful local revenue has a positive effect towards local expenditure. Similarly, [3] conducted a study using samples from District/City governments in the East Java Province in the year 2016. The study also showed that other lawful local revenue has a positive effect towards local expenditure.

\section{Flypaper Effect Analysis}

The sixth hypothesis is the flypaper effect. The presence of the Flypaper Effect can be identified if the component of fiscal balance transfer (GAF, SAF, RSF), has a more significant influence on Local Expenditure compared to the influence of Local Own-Source Revenue towards Local Expenditure [10]. Determining which independent variable is the most dominating or most influential towards the dependent variable can be done by using the values of the standardized coefficients [15], [16]. Analysis was conducted by considering the value of the standardized coefficients of the four independent variables, which are: local own-source revenue, general allocation fund, special allocation fund, and revenue sharing fund. In this analysis, the highest value of the standard coefficient originates from the general allocation fund, which is 0.514 larger than the value of the standardized coefficient of local own-source revenue. Meanwhile, the value of the standardized coefficient of the variable general allocation fund is 0.111 smaller than the standardized coefficient of local own-source revenue, which is 0.322 . The value of the standardized coefficient of revenue sharing fund is 0.213 smaller than the standardized coefficient of local own-source revenue, which is 0.322 . Therefore, it can be concluded that $\mathrm{Ha}_{6}$ is accepted, in which the flypaper effect is present in the component of the general allocation fund. The response of local expenditure is still more largely affected by fiscal balance transfers, specifically from the general allocation fund component.

\section{CONCLUSION, Limitations AND RECOMMENDATIONS}

This study aims to test to what extent have Local Governments been able to utilize their many revenue sources in making local expenditures with the factors that influence it, such as local own-source revenue, general allocation fund, special allocation fund, revenue sharing fund, and other lawful local revenue. Upon conducting analysis and hypothesis testing, the conclusion that can be drawn from this study is as follows: that sources of revenue received by Local Governments, such as local own-source revenue, general allocation fund, special allocation fund, revenue sharing fund, and other lawful local revenue, have the capacity to increase local expenditure. Therefore, in making local expenditures, local governments possess the opportunity to increase local expenditure by utilizing various available revenue sources, in which, local expenditure in this context is utilized to fulfil the needs of the district, such as building infrastructure, as well as repairing facilities and infrastructure for the people.

However, local expenditure in Districts/Cities in Indonesia experience the Flypaper Effect. The presence of the flypaper effect signals that the local governments have a tendency to become dependent on fund transfers from the central government, which causes local governments to become less independent. supposedly, aid from the central government can become a motivation to increase independence in districts in optimizing local potentials, so that local governments can rely on their local own-source revenue for funding. By using the value of standardized coefficients of each independent variable, it is known that the response of local expenditure is larger towards the general allocation fund, when compared to the response of local expenditure towards local own-source revenue.

For local governments, it is hoped that this study can provide information related to the factors that affect local expenditure. it is also hoped to become on of the consideration aspects for the local government with regards to the management of local expenditure, in which local governments can utilize other sources of revenue, such as the local own-source revenue, and not become solely dependent on transfers from the central government, so that the management of revenues owned can be optimally realized in order to improve public services and local infrastructure building for the sake of the people's welfare. For the next further study is hoped that they can add and test other variables that affect local expenditure, such as local tax.

\section{REFERENCES}

[1] Abdillah, K. \& Mursinto, D. (2016). The Effects of Financial Balance Transfer and Regional Own-Source Revenue on Regional Expenditure of Regencies and Municipalities in East Java Province. International Journal of Scientific and Research Publications, 6(5), 26-30

[2] Amalia, W. R., Nor, W. \& Nordiansyah, M. (2015). Flypaper Effect Pada Pendapatan Asli Daerah (PAD), Dana Alokasi Umum (DAU), Dana Alokasi Khusus (DAK) Terhadap Belanja Daerah Pemerintah 
Kabupaten/Kota di Provinsi Kalimantan Selatan (2009-2013). Jurnal Akuntansi dan Bisnis. 15(2), 96-105.

[3] Andrasari, Y., Nugroho, T. R. \& Ainiyah, N. (2016). Pengaruh Pendapatan Asli Daerah, Dana Perimbangan, Lain-lain Pendapatan Daerah yang Sah Terhadap Belanja Daerah (Studi Empiris Pada Kabupaten dan Kota Di Provinsi Jawa Timur Tahun 2016) (32), 1-14.

[4] Aprila, N. (2014). The Effect of General Allocation Fund (DAU) and Regional Real Income (PAD) on the Regional Expenditures (Empirical Studies of the Government District/city of the Province of Bengkulu). Malaysia Indonesia International Conference on Economics, Management and Accounting (MIICEMA 2014).

[5] Asari, A. N. M. \& Suardana, K. A. (2018). Pengaruh Pendapatan Asli Daerah, Dana Perimbangan, dan Lain-Lain Pendapatan Daerah yang Sah pada Belanja Daerah. E-Jurnal Akuntansi, 25, 877 https://doi.org/10.24843/eja.2018.v25.i02.p03.

[6] Astutik, E. N. P. \& Kuntara, A. D. (2017). Flypaper Effect and Factors Affecting Regional Government's Expenditure at Districts of Yogyakarta Special Region Province 2008 - 2014. Asian Academic Accounting Association.

[7] Aswar, K. (2019). Financial Performance of Local Governments in Indonesia. European Journal of Business and Management Research, 4 (6), 1-6. https://doi.org/10.24018/ejbmr.2019.4.6.164.

[8] Chandrarin, G. (2017). Metode Riset Akuntansi Pendekatan Kuantitatif. Jakarta: Salemba Empat.

[9] CNN Indonesia (2017). Sri Mulyani Keluhkan Pemda Terlalu Bergantung pada APBN.From cnnindonesia.com website: https://www.cnnindonesia.com/ekonomi/20171206135433-532260497/sri-mulyani-keluhkan-pemda-terlalu-bergantung-pada-apbn.

[10] Dewi, S. R. (2017). Flypaper Effect, PAD, DAU, DAK Terhadap Belanja Daerah Di Kabupaten/Kota Di Indonesia. Journal of Accounting Science, 1(2), 155. https://doi.org/10.21070/jas.v1i2.956.

[11] Ekawarna, S. U. (2017). Analisis Flypaper Effect pada Belanja Daerah (Studi Komparasi Daerah Induk dan Pemekaran kabupaten/kota di Provinsi Jambi). Jurnal Perspektif Pembiayaan Dan Pembangunan Daerah, 4(3), 2338-4603.

[12] Ermawati, E. \& Aswar, K. (2020). Assessing Regional Finance Independence in Indonesian Local Governments. European Journal of Business and Management Research, 5(1), 1-5. https://doi.org/10.24018/ejbmr.2020.5.1.178.

[13] Ernayani, R. (2017). Pengaruh Pendapatan Asli Daerah, Dana Alokasi Umum, Dana Alokasi Khusus dan Dana Bagi Hasil terhadap Belanja Daerah (Studi Kasus pada 14 Kabupaten/Kota di Provinsi Kalimantan Timur Periode 2009-2013). JSHP (Jurnal Sosial Humaniora Dan Pendidikan), 1(1), 43. https://doi.org/10.32487/jshp.v1i1.234.

[14] Fatimah, N. N., Nopiyanti, A. \& Mintoyuwono, D. (2018). Pengaruh Pendapatan Asli Daerah dan Dana Perimbangan Terhadap Belanja Daerah. Jurnal Equity, 21(1), 1-16.

[15] Ghozali, I. (2013). Aplikasi Analisis Multivariate Dengan Program IBM SPSS 21 Update PLS Regresi (Edisi 7). Semarang: Badan Penerbit Universitas Diponegoro Semarang.

[16] Ghozali, I. (2016). Aplikasi Analisis Multivariete dengan Program IBM SPSS 23 (Edisi 8). Semarang: Badan Penerbit Universitas Diponegoro Semarang.

[17] Halim, A. (2016). Manajemen Keuangan Sektor Publik (2nd ed.) Jakarta: Salemba Empat.

[18] Jatmiko, B., Prawoto, N., Astuti, R. J., Pradipta, W. T. \& Mulyani, T. I. (2016). The Impact of Flypaper Effect and Gross Regional Domestic Product To Ward Regional Expenditure. ICBAE 107-119.

[19] Juliana, F, S. (2013). Analisis Hubungan DAU, PAD dan Belanja Daerah Di Kabupaten Mihasa Selatan. ISSN 2303-1174, Jurnal EMBA 1(3) September 2013, 171-180.

[20] Keuangan (DJPK), D. J. P. (2018). Ringkasan APBD 2018.

[21] Kemenkeu.go.id. (2019). Ini “Catatan" Menkeu Terhadap Pengelolaan APBD yang Kurang Optimal. Retrieved February 3, 2020, from www.Kemenkeu.go.id https://www.kemenkeu.go.id/publikasi/berita/ini-catatan-menkeuterhadap-pengelolaan-apbd-yang-kurang-optimal/.

[22] Lestari, Sri Dewi \& Ni Gusti Putu Wirawati. (2016). Good Corporate Governance sebagai Pemoderasi Pengaruh Asimetri Informasi pada Manajemen Laba. E-Jurnal Akuntansi Universitas Udayana, 16 (1), 156-182.

[23] Merdeka.com. (2019). Mendagri Soroti Temuan Permasalahan Berkaitan Alokasi APBD. Retrieved March 17, 2020, from Merdeka.com website: https://www.merdeka.com/peristiwa/mendagrisoroti-temuan-permasalahan-berkaitan-alokasi-apbd.html.

[24] Nurdiwaty, D., Zaman, B. \& Kristinawati, E. (2017). Analisis pengaruh pertumbuhan ekonomi, pendapatan asli daerah, dana perimbangan dan lain-lain pendapatan yang sah terhadap belanja modal di kabupaten/kota Jawa Timur. Jurnal Aplikasi Bisnis, 17(1), 43-59. https://doi.org/10.20885/jabis.vol17.iss1.art3

[25] Pratami, A. A. P. N. I. \& Dwirandra, A. A. N. B. (2017). Pengaruh PAD, Dana Perimbangan, LPDS, Dan PDRB Pada Belanja Daerah Serta Deteksi Ilusi Fiskal. E-Jurnal Akuntansi Universitas Udayana, 18(2), 1141-1170.

[26] Putra, I. B. D. \& Dwirandra, A. A. N. B. (2015). Dana Alokasi Umum, Dana Bagi Hasil, Dana Alokasi Khusus Dan Pendapatan Asli Daerah Provinsi Bali. E-Jurnal Akuntansi, 13(3), 811-827.

[27] Rini, N., Wiranto, A., \& Farida, Y, N. (2014). Analisis Flypaper Effect Pada Dana Alokasi Umum (DAU), Dana Alokasi Khusus (DAK), Dana Bagi Hasil (DBH), Dan Pendapatan Asli Daera (PAD) Terhadap Belanja Daerah (BD) Kabupaten/Kota Di Jawa Barat. Jurnal Akuntansi dan Keuangan, 2 (1).

[28] Shita, U, E. (2017). Analisis flypaper effect pada belanja daerah (studi komparasi daerah induk dan pemekaran kabupaten/kota di provinsi Jambi). Jurnal Perspektif Pembiayaan dan Pembangunan Daerah, 4 (3), 167-184.

[29] Tololiu, R. J., Walewangko, E. N. \& Tumangkeng, S. Y. L. (2018) Analisis Pengaruh Pendapatan Asli Daerah , Dana Alokasi Umum, Dan Lain-Lain Pendapatan Yang Sah Terhadap Belanja Daerah D Kabupaten Minahasa. Jurnal Berkala Ilmiah Efisiensi, 18(6), 56-70.

[30] Undang-Undang Republik Indonesia Nomor 32 Tahun 2004. (2004). UU Nomor 32 Tahun 2004. Undang-Undang Republik Indonesia

[31] Undang-Undang Republik Indonesia Nomor 33 Tahun 2004. (2004). UU Nomor 33 Tahun 2004. Undang-Undang Republik Indonesia.

[32] Yulina, B., Sari, K. R., Martini, R., Dewi, H. H. S. \& Safitri, K. A. (2017). Fenomena Flypaper Effect Pada Dana Perimbangan Dan Pendapatan Asli Daerah Pemerintah Kabupaten / Kota. Jurnal Riset Terapan Akuntansi, 1(2), 89-96. 